\title{
Macroeconomic Perspective on Urban Sprawl: A Multidimensional Approach in Poland
}

\author{
Piotr Lityński (D) and Artur Hołuj *(D)
}

Citation: Lityński, P.; Hołuj, A Macroeconomic Perspective on Urban Sprawl: A Multidimensional Approach in Poland. Land 2021, 10, 116. https://doi.org/10.3390/ land10020116

Academic Editor: Fabrizio Battisti Received: 23 December 2020

Accepted: 23 January 2021

Published: 26 January 2021

Publisher's Note: MDPI stays neutral with regard to jurisdictional claims in published maps and institutional affiliations.

Copyright: (c) 2021 by the authors. Licensee MDPI, Basel, Switzerland. This article is an open access article distributed under the terms and conditions of the Creative Commons Attribution (CC BY) license (https:// creativecommons.org/licenses/by/ $4.0 /)$.
Department of Spatial Management, Faculty of Economy and Public Administration, Cracow University of Economics, 27 Rakowicka St., 31-510 Cracow, Poland; litynskp@uek.krakow.pl

* Correspondence: holuja@uek.krakow.pl

\begin{abstract}
There are important relationships between the urban sprawl process and economic growth They are usually expressed through spatial relations and changes taking place in the local, regional and national economy. The temporal and spatial dimension, including dispersed location, are the determinants of development and economic growth. Therefore, the urban sprawl phenomenon and the related location, hypothetically conditioning economic growth, should be subject to macroeconomic research. The article examines how urban sprawl affects the national budget and national economic growth. Unlike many studies where urban sprawl is studied by scattering the population around cities, we undertake more complex examination using buildings' location. Urban sprawl, as we understand it, is a spontaneous spread of buildings around cities. To assess the spontaneity, we use a grid of squares with a side of $500 \mathrm{~m}$. The squares are used to calculate the morphological indicators of urban sprawl. Therefore, quantified urban sprawl is one side of the equation; on the other side are macroeconomic variables. In this way, we examine the relationship between urban sprawl and the national budget and economic growth of Poland. The conclusions obtained are, e.g., urban sprawl does not have a negative effect on the national economy and the budget. This is a different conclusion from those thus far. There are also different conclusions on the regional level. Based on the research results, we formulate recommendations for national economic policy and spatial policy.
\end{abstract}

Keywords: urban sprawl; macroeconomics; externalities; budget; spatial policy; economic policy

\section{Introduction}

Urban sprawl has been a phenomenon discussed in literature since the middle of the last century [1]. This phenomenon is usually identified with a chaotic reorganization of spatial structure of suburban communes with a simultaneous low impact of local spatial policy [2]. The result of this process is the dispersion of buildings in the suburban area, the edge of the city, the metropolitan area or functional area of the core city [3]. Scattering of buildings is associated with the composition of specific, negatively valued morphological features, which include: low building density, lack of spatial continuity, lack of concentration of buildings, lack of buildings' clustering, spatial decentralization, polynuclearity, and lack of mixed land use, lack of proximity [4]. Moreover, it is important from the cognitive point of view to describe the factors that trigger urban sprawl. Despite the fact that the intensity, distribution or parity will have an individual impact on the selected space, some similarities and features are noticeable in them [5]. The urban sprawl process is influenced by local, spatial, historical and economic conditions. Therefore, several groups of related factors can be distinguished. A commonly identified factor in urban sprawl is the process of social development, which is the source of favorable population changes in the city. The reason for the indicated changes is the natural increase and intensified migration to the urban area [6]. The indicated process of social development is reflected in the local and regional economy. Therefore, another group of urban sprawl factors is distinguished in micro and macroeconomic terms. In the first case, the main role is played by: household 
preferences in terms of place of residence, as well as financial possibilities and constraints. The macroeconomic context of urban sprawl related to a country's economic growth usually comes down to the distribution of the economic base in the region. Another group of factors is related to the form and decision-making possibilities of entities from the real and regulatory sphere of the economy. The importance of territorial entities is usually reduced to the role played by spatial policy entities in a given country. The authorities at the central level create the general framework (legislation, rules of conduct, etc.) necessary to conduct spatial policy (development policy), while the municipal authorities are responsible for indicating the destination and spatial development at the local level (location policy, investment policy in the field of real estate trading, etc.). Independence, equity and compliance with the guidelines for making decisions by the indicated entities are important here. Also, resistance to the influence of other actors operating in the space for which the generally available and currently binding standards and regulations are not satisfactory. The last important group of urban sprawl factors is closely related to the suburban local investment and speculative conditions of land, including geographic and environmental conditions as well as technical infrastructure.

In parallel to the discussion on the specificity of urban sprawl, the economic consequences of urban sprawl have already been discussed [7]. The economic costs are first and foremost, the increase of public expenses covering construction, extension, and maintenance of infrastructure and public services, extended commuting distance; the consumption of energy and market-related negative influence on the city center [8-12]. The negative impact of sprawl on household budgets is associated mainly with the extension of the use of cars. Economic consequences of the phenomenon manifested in the increased number of vehicles per household, which led to an increase in expenditure on: fuel, insurance, maintenance of vehicles, the periodic purchase of new vehicles [13]. There are also conclusions in the literature about the potential economic benefits of urban sprawl. O'Toole (2009) has argued that sprawl, thanks to the automobile, gave rise to affordable suburban neighborhoods for middle-class and lower-class individuals [14]. The studies cited are micro- or mesoeconomic assessments, while research on macroeconomic consequences is rarely undertaken. Therefore, we can pose the question of how urban sprawl affects the national economy, its growth or the condition of the state budget?

When discussing the national macroeconomic perspective, economic growth is usually disaggregated into dimensions: sectoral, temporal and spatial [15]. The impact of urban sprawl is, therefore, a component of economic growth in both spatial and temporal dimensions. This influence is expressed in spatial relations and changes taking place in the local, regional and national economy. Mankiw et al. they indicate that the location and the environment understood as anthropogenic conditions are a significant determinant of economic growth [16]. The location, especially the scattered one, is an inherent feature of urban sprawl. Therefore, the urban sprawl phenomenon, while theoretically determining economic growth, should be subject to macroeconomic research. On the other hand, the surroundings of the location extend the discussion on the macroeconomic effects of urban sprawl to include externalities. Research and analyzes presented in the literature on external effects focuses on the dependencies caused in local and regional systems and at the institutional level, in the absence of analysis concerning a macroeconomic perspective [17-21]. In the light of this literature, the externalities of urban sprawl justify the formulation of public policy, including economic and spatial, influencing this phenomenon. Apart from a few exceptions, the macroeconomic urban sprawl and its relation with public policy are not widely undertaken in Poland [22].

Taking into account the current state of knowledge, and in particular the gap in the macroeconomic assessment of urban sprawl, the aim of the study is to identify the costs and benefits of urban sprawl at the level of the national economy. As the macroeconomic perspective of urban sprawl permeates the literature with the assessment of externalities, and then with the undertaken spatial policy, the theoretical part explains: the essence of urban sprawl externalities, its macroeconomic costs and benefits, and the instruments of 
influencing sprawl. Two hypotheses were proposed in the research part: $H(1)$ : Urban sprawl adversely affects the financial situation of the national budget; $H(2)$ : Urban sprawl slows down the growth rate of the local and national economy. However, the summary presents the results of the research against the background of the literature and formulates recommendations for public policy.

\section{Urban Sprawl Externalities as the Basis for Public Intervention}

\subsection{The Essence of Urban Sprawl Externalities}

Since the middle of the last century, cities have been subject to many dynamic and multidirectional changes, i.e., urbanization, metropolisation, decentralization, revitalization, re-urbanization [23]. This evolution of spatial structures is a derivative of pro-or anti-urban behavior and views [24,25]: from urban concentration, through suburbanization to non-metropolitan changes [26]. The variety of trends and phases of development triggers various external effects, which are the premises for state interventionism, including spatial policy.

Economists argue that externalities are generated when an individual imposes costs on or brings benefits to others, and they have no economic incentive to accept these costs or benefits [27-30]. As a result, we observe positive and negative externalities, generated during consumption or at the stage of production itself. Externalities can, therefore, be generated during spatial management, i.e., during the aforementioned trends in city transformations. Therefore, we identify the complexity of the process, magnified by the variety of causes that result in a given effect. The observed reasons are mainly problems with identifying the ownership rights of public and private goods, as well as complementary and substitute goods. Moreover, in identifying externalities, the form of using goods and benefiting from them is important. Therefore, it is reasonable to conclude that when externalities occur, state intervention will not always be needed. Externalities leading to socially acceptable costs will not be a prerequisite for formulating public policy. We must remember that state interventions also generate externalities [31].

Externalities of urban sprawl should be equated with the effects of private and public activities. In regard to private entities, externalities occur when the location of the development of one side improves or worsens the situation of another party, however, until the party generating external effects does not bear the costs of its activities. On the other hand, in regard to public entities, externalities are associated with the improvement or deterioration of the situation of entities operating in space, due to the low degree of control of spatial processes by the local government sector. The behavior of the local government sector entities is sometimes completely uncontrolled, unconscious, or even irrational.

Moreover, public intervention is used in the preferential treatment of certain entities. It is a derivative of the activities performed in the field of providing public goods. Preferential solutions come down to displacing market mechanisms by administrative determination of the costs of production factors, prices and methods of distribution of certain goods [32]. Externalities of urban sprawl are also identified in the area of the emerging relationships between individual users of suburban space. As a consequence, we can see externalities being to a large extent the aftermath of the implemented spatial policy. These effects have specific forms, such as: external benefits and costs; monetary and non-monetary, i.e., technological; unilateral and multilateral, and private transferable and public nontransferable [33].

\subsection{Macroeconomic Costs and Benefits of Urban Sprawl}

Special attention should be paid to the losses and spatial benefits resulting from the urban sprawl process. Spatial losses are reduced (incurred damage) or unattained (lost opportunities) social benefits from the use of resources and values of space. Moreover, we observe that the phenomenon of transferring some of the costs resulting from space development processes to third parties, usually residents, is a common process. The current and future prosperity of the local community, understood as the quality of life in space, is 
depreciated. The relationships between the private and social optimum also seem to be important, because they can generate measures of pure intervention.

The proposed approach to the problem does not eliminate other, non-market concepts of losses, e.g., natural or ecological losses. As a result, irreversible damage to the natural environment occurs. This damage is covered by direct market reactions, and spatial benefits are equated with positive effects. They occur simultaneously with the launch of the intervention process limiting the sources of space depreciation. Losses always accompany diminished natural resources. Losses and spatial benefits in the theory of economics are included as external costs and benefits. On the other hand, the use of the values of the environment with a simultaneous downward trend in creating new sources of benefit is expressed through environmental external costs. Taking into account macroeconomic conditions, direct losses can be presented as negative spatial consequences expressed as a reduced environmental potential and indirect ones resulting from spatial development, where there is a division into social and economic losses.

Urban sprawl causes a number of threats, in the natural, social and cultural area. These threats are characterized by a varied scale and form of externalities closely related to the local conditions of socio-economic processes. The lack of urban development planning can be equated with the unplanned and successive growth of urban areas [34]. The observed direct effect of this are monofunctional spatial structures embedded in discontinuous functional and territorial systems. Therefore, the question arises whether urban sprawl processes should not be treated as one of the stages in the development of highly urbanized space? The scientific literature of the last decades has ambiguously interpreted the existing settlement patterns [35]. The space in which man functions is characterized by various features, and one of them is resistance. The resistance of space should be identified primarily with the costs of transport, the costs of moving people, goods, information services. Common internal migrations, their dynamics and the method of analysis are also important.

There are numerous theories discussing demographic and spatial patterns, current and historical trends, or even conflicting interpretations of them. In almost each of them, the problems of the core city, suburbs and rural areas are assessed [36,37]. Typically, these studies focus on the "target" space where relatively most external effects of the urban sprawl process are identified. Depending on various local factors, also on the availability of input data or sometimes research interests, the analysis also covers circular migrations and the morphology of rural areas $[38,39]$. Some studies show that counterurbanization has entered a new phase characterized by a new destination of the observed flows [40]. It is characterized by a significant differentiation in individual countries in terms of causes, intensity of trends, etc. It can also be considered in a variety of perspectives, from local, to regional and national [41,42]. The process of counter-urbanization has been observed since the 1960s in Western Europe [43,44] and the USA [45,46]. Its identification sometimes requires interdisciplinary knowledge, as evidenced by research carried out in the disciplines of geography, economics or sociology. One interpretation of this concept points to a faster growth of suburban areas than urban areas. We see a similar situation in nonmetropolitan and metropolitan spaces. Ref [42] Contrurbanization generates diversified circulation of resources in the city-village and village-city space. However, the most frequently indicated in the research is the migration of the population towards the areas characterized by a lower concentration [47]. There are many reasons for the migration of people to rural areas, it can be generally stated that it is a search for better living conditions, closer to nature [41,48]. Nevertheless, urban migrants (related to counterurbanization) in a sense give up their permanent relationship with the city. They choose areas further away from the city/metropolitan core. They give up the current comfort of the impact of the urban fabric, its resources and amenities. They are usually wealthy and not of retirement age [49]. Considering the migration theme, they should be considered as voluntary migrations. In this context, we can observe a clear difference between the processes of counter-urbanization and suburbanization, where in the case of the latter, 
along with the migratory movements of the urban population to rural areas, important professional, infrastructural, educational, etc. Ultimately, most researchers have both valid and incomplete research results because the structure chosen has not received sufficient attention [50]. Because urban sprawl can take many forms, the effects it generates may have a diverse structure, reach and audience. Burchell et al. (2005) indicate that urban sprawl processes are characterized by an unfavorable macroeconomic impact [51]. Irreversible loss of agricultural land generates negative externalities that are transferred to the neighboring agricultural activities, where productivity, quality of crops, etc. will be limited. There will be problems in the use of mechanized agricultural technologies, including the necessary biological and chemical care of plants. Over time, restrictions are set for other farmers, limiting their functioning. And farmers will limit production for fear that this process will not be profitable. The pressure generated by the users of residential areas in the aftermath of urban sprawl will also increase: various conflicts of interest, for example in the case of the need for water necessary for functioning in housing and agriculture. Burchell et al. (2005) also indicate that the loss of the agricultural function is not compensated for by the amount of a one-off purchase and sale transaction of agricultural land for housing development. There are also studies with different conclusions, which indicate that urban sprawl does not have a negative impact on the national economy $[25,52,53]$. However, in the case of the local level, not very resistant to dynamic changes or economic fluctuations, the situation seems to be more complicated. Economic growth is the result of various stimulating and destabilizing conditions, causing the state of the local economic crisis [52,54]. In this context, one should bear in mind the course of business cycles and the inevitable economic crises. The recent crisis in southern Europe should undoubtedly be mentioned as a painful example of this. Its most important factors include a very high level of investment risk, social polarization and an economy that intensively exploits natural environment resources [55]. The crisis in Spain caused a direct fracture of the housing bubble resulting from failures in spatial planning and irrational land management [56,57]. As additional reasons for the state of affairs, one should apply to the management method, the implementation of spatial and economic data and relations with local communities (e.g., social guarantees). Spatial planning and development issues have been discussed earlier, it is worth paying attention to the attitudes and beliefs of the local population (including social participation). It is the residents, their attitudes and respect for and commitment to the available space that a lot depends on [58]. There is also a question, whether they will be willing to stay and function in the city, or will they be forced to move to the suburban area to look for the desired social conditions (both will result in financial losses [59]). The observed evolution of the rural spatial structure generates socio-economic changes in local and regional systems. Rural restructuring, identified with its urbanization, was originally attributed to a positive assessment of this process. However, as research shows, urbanization of rural areas also triggers undesirable phenomena causing depreciation in the field of technical infrastructure and spatial structure of villages. There are also unfavorable depopulation phenomena and negative changes in socio-economic structures. The result of the restructuring of rural areas in Poland was a significant increase in the dispersion of buildings and the development of rural areas with large-scale production and housing units [60]. Rural areas are highly diversified in terms of their concentration and compactness, functions, morphology or the pace of urbanization. They have various natural, landscape, cultural conditions, etc. It should also be noted that thanks to the restructuring of rural areas in many countries, e.g., in Poland, Spain, agricultural areas within the metropolitan area gained new economic and tourist functions, etc., and the lifestyle of their inhabitants was changed. However, it cannot be unequivocally concluded that these changes completely restructured the village [61]. Moreover, how much influence will the neoliberal economy implemented in many countries have on urbanization processes? Its effects often have very serious consequences affecting planning and functioning in space $[55,62]$. 


\subsection{Instruments for Influencing Urban Sprawl}

The basic instrument for influencing urban sprawl is an efficient spatial policy, which is based on the legal and administrative requirements of the commune and the state. It is a regulatory approach serving to create the legal as well as regulatory and organizational basis affecting urban sprawl. Such instruments include: acts and regulations, standards, land use plans, geodetic divisions, zoning, construction and town planning standards and various administrative decisions of a permitting, mandating, prohibiting and penal character. On the basis of formal and legal documents, various coercive measures as well as incentive or discouraging measures are generated, affecting directly or indirectly on space users, investors, economic entities, etc. The indicated spatial policy is based primarily on operational, action, structure, development, sectoral plans, pilot; local and regional strategies of development, infrastructure projects, etc.

Land development can be indirectly influenced by operational economic instruments, i.e., discounts, taxes and subsidies. The forms of direct aid take various forms, including [63]: preferential land prices, loans or loan guarantees, differentiation of the property tax rate, subsidizing infrastructure investments, transport, etc. Another group of effective instruments are solutions for material profiling of space. The authorities, especially the local ones, may influence spatial decentralization by the appropriate location of technical infrastructure and social infrastructure. The potential advantage of location is a common argument, especially when making decisions on residential investments, carried out by private individuals and developers. There are instruments of "soft" impact on urban sprawl, but their effectiveness is not always predictable. These are various activities of entities, development agencies, corporations, development banks, etc. operating on the basis of delegating the powers of public authorities in the field of spatial management. It will also be important to influence the behavior of space users based on urban marketing and various information materials; promotion, location ads, built "genius loci", outdoor meetings, promotional gadgets, campaigns in social media, etc.

The aforementioned territorial entities have various causative powers, as well as various impacts on the development of space and urban sprawl processes. This fact results from the heterogeneity of the instruments of influence assigned to them. The scope of their duties is subject to arrangements with government and local government administration bodies (in accordance with the relevant provisions of the Code of Administrative Procedure). In most cases, planning studies at the local level are subject to supervisory control conducted by representatives of the regional government (sometimes representatives of the central administration). Moreover, the decisions of local and regional commissions of appeal may be the subject of a matter before the substantively competent administrative courts. The spatial development law systems in Europe are also varied in terms of the way public authorities are coordinated at the local level. The basic difference comes down to the formula of this coordination which accepts, inter alia, the form of planning documents, legal acts or agreements.

When implementing spatial policy, we must take into account the needs of the local community, including social ones. Some scientific studies provide a valuable analysis of the issues of social exclusion and threats identified in urban structures [58]. Residents have the right to actively participate in the space management process, and their role definitely grows when their legal interests are violated.

The use of operational and "soft" instruments influencing urban sprawl in spatial policy depends on the planning system in the country, for example: British, Germanic, Napoleonic, Scandinavian and Central and Eastern European countries. As Newman and Thornley [64] indicate, these systems are built independently, however, in accordance with applicable standards and generally recognized good practices. Therefore, they are universal and open to local planning challenges. Following the standards of planning procedures, the current form of development is subject to legal protection, necessary verification and positive assessment by the local authority. The lowest-level public administration units have planning powers. The aim of the planning decisions made is to achieve optimal 
solutions that serve the interests of the general public and the interest of the individual. The potential "optimum" is achieved by defining target, precise and justified local conditions of land development.

The indicated forms of spatial planning as the main goal of their activities set, among others rational and efficient spatial management and preventing urban sprawl. The Germanic system used in Germany, Switzerland, Austria and partly in Eastern Europe, e.g., in Poland, incorporates the land-use plan "Flachennutzunsplan" at the municipal level. In Poland, it is "a study of the conditions and directions of spatial development in a commune". These studies determine the local spatial policy. In order to detail the development conditions, a development plan "Bebaunsplan" is prepared; in Poland it is "the local spatial development plan of the commune". The British system (England, Wales, Scotland and Ireland) uses a document in the space management process that allows for activities in the space called "planning permission", issued by districts and unitary authorities.

On the other hand, the Napoleonic system is used in: France, Luxembourg, the Netherlands, Italy, Portugal, Belgium, Spain and Greece. It is a system in which statutory law takes precedence, on the basis of which detailed legal norms are established, and the principles of spatial planning are defined comprehensively. The local level is legally required to have spatial planning acts, but there is no clearly defined level of accuracy of these studies. For example, in the spatial planning system in Spain, despite the established core of the planning procedure for individual autonomies, there is no obligation to agree on the provisions of planning documentation between neighboring municipalities. In the case of the Scandinavian system in force in Denmark, Sweden, Norway and Finland, based on transparent and uncomplicated legislation, it draws different proportions from the Napoleonic and Germanic systems. For example, in Sweden, the implementation of spatial policy was based on the development of comprehensive plans "oversiktsplaner" and on the local level detailed spatial development plans "praktjpla" and "conditions for spatial development of the area". It is worth emphasizing that the local (bottom-up) level is the most important element in the Swedish planning system.

The implementation of spatial policy in the discussed countries is associated with the ongoing process of spatial management. This process is directly influenced by the form of spatial management and the specificity of real estate markets, including their location (urban, suburban and rural areas). The price of the property plays a leading role in making the decision. It is the result of many factors (location, building method, availability of technical infrastructure, surroundings, labor market, etc.). Therefore, the dynamics and methods of land use, the recomposition of functions in selected spaces and the costs and benefits generated by the reorganization of planning functions are important. They depend on the specificity of the spatial planning tools used. Also, from the administrative division of the country, for example in Spain, the law obliges the plan to cover the entire area of the commune (there may be several). In Poland, the local plan is prepared optionally (in a commune there may be even several dozen plans, a situation in which not a single document will be prepared is also acceptable). Apart from that, as a rule, in Poland there is one type of local and regional plan. They are dedicated to urbanizing and urbanized areas, as well as typically agricultural areas. On the other hand, in Spain there are as many as nine types of plan, five of which are used for urban design and four for territorial planning [65]. From the planning point of view, these countries seem to be similar due to the levels of administration. There is a municipal level in both countries. The province in Spain corresponds to the regional level, and the voivodeship in Poland. In both cases, the principles of the country's spatial policy are prepared at the national level, together with recommendations for the regional and local level. There are more similarities and analogies between the European Union (EU) countries in terms of spatial planning [66]. It is necessary to pay attention to detailed conditions, including issues that determine the effectiveness of the designated spatial policy. Effective land management based on efficient legislation will also be important. In order to efficiently influence spatial processes, including urban sprawl, skillful land 
structuring is needed (in Spain, land is divided into three classes: I for urbanization; II intended for urbanization; III with no possibility of urbanization). In Poland, an effective solution for specifying the intended use of land is a local plan, which is also local law. Areas not included in this document may be, with minor inclusions (e.g., legally protected areas), freely developed, especially when it comes to housing development on agricultural land. This fact results in the intensification of urban sprawl. Procedures can be simplified, local communities can be significantly involved in the planning process, and policies aimed at optimizing the development of available land can be sought. Various functions can be combined within the planning system, including the expansion of the control system. However, their effectiveness should be considered individually. Interest in space by its users, and thus the observed population density will be determined each time by local possibilities and needs. As research shows, the available technical infrastructure is of great importance, as well as the form of spatial structure development resulting, among others, from the demand for residential or industrial areas [67,68]. Gomez-Antonio and Hortas-Rico [2014] prove that urban sprawl is taking place in Spain [69]. They also indicate that the emergence of urban sprawl in the communes surrounding the city intensifies when sprawl occurs in a neighboring commune. The morphological specificity of urban sprawl in Mediterranean regions is manifested in low urban densities, high losses of nonurban land covers, depopulation of the metropolitan inner core, increasing importance of single housing and the expansion of transportation infrastructures [70,71]. Apart from technological factors and the development of road transport, geographical factors, such as topography and the area's technical infrastructure, play an important role in the escalation of urban sprawl [72,73].

The practice of space management, unfortunately, highlights its various shortcomings, the source of which is still, among others, insufficient knowledge and competences, lack of respect for space and its users, or actions deliberately aimed at quick and short-term profit.

Generally, the availability of instruments, including legal ones, to counteract urban sprawl processes to a large extent depends on the planning system of a given country, applicable standards and commonly used good practices. The available spatial data, without which a diagnosis is difficult, are also important and, therefore, the selection of instruments for influencing the space becomes problematic [74].

\section{Materials and Methods}

The adopted research objective, which is to identify the macroeconomic costs and benefits of urban sprawl, results from the ambiguity of the current state of knowledge regarding the effects of the process in question. In order to achieve the goal, the verification of two hypotheses supposing a negative macroeconomic impact of urban sprawl was assumed, i.e.:

Hypothesis 1 (H1). Urban sprawl adversely affects the financial situation of the national budget;

Hypothesis 2 (H2). Urban sprawl slows down the growth rate of the local and national economy.

To verify both hypotheses, studies were proposed in regard to the area affected by the urban sprawl phenomenon in Poland, described by Lityński and Hołuj [75]. This area is presented in Figure 1 and consists of communes located around the capitals of regions or core cities in Poland. Communes in the zone external to the capitals and cores are: 50 cities, 221 villages, 99 town-villages. It should be mentioned that there are three types of commune in Poland: urban, that is cities; rural, i.e., a village with a low degree of urbanization; urbanrural, i.e., a city surrounded by rural areas. It should be explained that the analyzed urban areas have the same administrative status and are among the most important in Poland, as they are the areas surrounding the capitals of the regions. However, not all urban areas in Poland were analyzed, i.e., urban areas that belong to a lower level in the hierarchy of the Polish settlement system were not analyzed. Despite this, the area taken for research covers $15 \%$ of the territory of Poland, where $25 \%$ of the country's buildings are located. It seems to 
be a representative sample. For the 370 indicated communes, Lityński [6], using the urban morphology indicators defined by Galster et al. [4], calculates variables: density (Diu), continuity (Ciu), concentration (COViu), clustering (CLUSiu), decentralization (CBDdist), urbanization pressure $(\mathrm{UPj} \rightarrow \mathrm{i})$. This area and quantified morphological are the starting point for research into the economic consequences of urban sprawl.

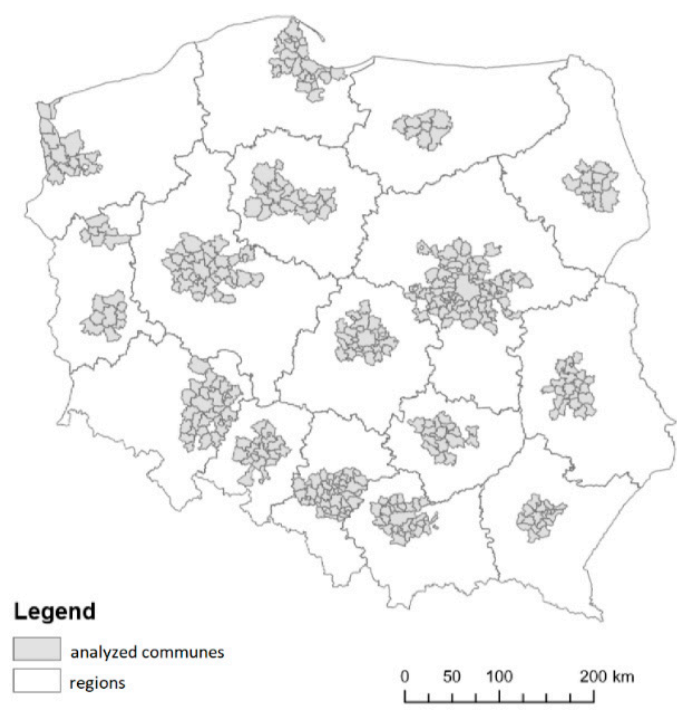

Figure 1. Analyzed area. Source: own based on Lityński \& Hołuj [6,75].

Lityński [6] proves that urban sprawl occurs in the analyzed urban areas, which are subject to population migrations from central cities to the suburbs. The physical manifestation of urban sprawl is the remoteness of residential buildings from the core city. New residential buildings are located in agricultural areas, which has been described pejoratively as urbanization pressure. Despite the fact that the buildings are far from the core cities, the composition of the buildings is dense and clustered, maintaining spatial continuity. However, this composition results from the vicinity of new residential buildings with old agricultural buildings. Lityński [6] also emphasizes the significant differentiation of the morphological specificity of urban sprawl between regions, i.e., in selected urban areas other morphological indicators dominate.

The urban sprawl assessment can be presented in an international context. For example, an Organization for Economic Cooperation and Development (OECD) report [76] dealing with the issues of assessing urban sprawl in OECD countries draws attention to this. This report indicates that Polish urban areas are characterized by a higher density than the OECD average. In the light of the measures of the spatial structure of Lityński [6] using the building density, this conclusion can be confirmed. It can also be partially confirmed in the report's conclusion that Polish urban areas are less polycentric than in other OECD countries. This is partly because, as previously signaled, Lityński [6] generally indicates a monocentric character, but in Poland urban areas differ significantly in this respect. The report also indicates that Polish urban areas are less fragmented than the OECD average, which can also be confirmed through the prism of continuity, concentration and clustering indicators. However, the report does not attempt to assess the specificity of spatial development, i.e., its filling, and the presented assessment of urban sprawl, show high urbanization pressure on agricultural areas. These results make it possible to compare the specificity of the Polish sprawl with other OECD countries, to search for similarities and differences. According to the OECD report [76], similar conditions to the Polish urban sprawl can be attributed to Spain. From the morphological side of urban sprawl, both countries show a higher density. Despite this density, building clusters are more fragmented than in other OECD countries. The difference between the two countries is centralization, which in Spain shows the proximity of buildings to core cities, and in Poland its remoteness. 
The study was divided into three stages. The first stage consists of assessing the urban sprawl phenomenon in each of the analyzed communes. The purpose of such an assessment is to identify communes with a high and low degree of disorder in the spatial structure that is attributed to urban sprawl. Identifying communes with a high degree of urban sprawl is important in examining economic consequences and verifying hypotheses. For this purpose, Lityński's morphological indicators were synthesized [6] based on the Perkal method:

$$
P_{i}=\frac{1}{p} \sum_{j=1}^{p} z_{i j}
$$

where:

$z_{i j}$-normalized variable: $z_{i j}=\left(x_{i j}-\bar{x}_{j}\right) / s_{j}$ for stimulant or $z_{i j}=\left(\bar{x}_{j}-x_{i j}\right) / s_{j}$ for destimulant

$\bar{x}_{j}$-average value of variable $\mathrm{j}$

$x_{i j}$ - value of variable $\mathrm{j}$ for the commune $\mathrm{i}$

$s_{j}$-standard deviation of variable $\mathbf{j}$

$p$-number of variables

The Urban Sprawl Index, built on the basis of the Perkal (Pi) method, ranges from -3 to +3 . Communes with a high degree of spontaneous spatial structure will show values below 0 , areas with a moderate degree of the phenomenon will oscillate around 0 , and the area with a relatively low degree will record values above 0 . Similar areas are considered to be those with similar index values. Identification of communes for which $\mathrm{P}(\mathrm{i})<0$ will allow to indicate in the research communes the specificity of the disorder of the spatial structure, which is attributed to urban sprawl. With regard to these communes, research on the economic impact of urban sprawl will be continued.

The second stage involves a verification of $\mathrm{H}(1)$. It was decided to verify the hypothesis based on the canonical analysis. The value of the canonical analysis is the assessment of the relationship between two sets of variables. In the case of the presented research, it will be a comparison of morphological variables with fiscal variables. Morphological variables are the aforementioned: $\mathrm{D}(\mathrm{iu}), \mathrm{C}(\mathrm{iu}), \mathrm{COV}(\mathrm{iu}), \mathrm{CLUS}(\mathrm{iu}), \mathrm{CBD}(\mathrm{dist}), \mathrm{UP}(\mathrm{j} \rightarrow \mathrm{i})$. These variables are referred to in the literature as urban sprawl features [3,4]. Fiscal variables are three types of state budget expenditure for communes: supplement to the general subsidy (SGS); subsidies for own current tasks (SOCT); subsidies for own investment tasks (SOIT).

It should be noted that in Poland there is an extensive system of transfers from the national budget to the budgets of communes. Among the many types of transfer, from the point of view of the subject of this research, SGS is important. It is an expenditure of the national budget for selected communes with income and expenditure disproportions. It pertains to the high costs of implementing communes' own tasks (e.g., building communes' roads), the implementation cost of which is higher than in other units due to specific conditions. On the other hand, SOCT and SOIT are funds transferred from the national budget to communes for the implementation of previously specified tasks in the field of roads, education and sport. The difference between SGS and SOIT is that SOIT is generic, while SGS must be spent on a specific task and unused funds must be returned. In this context, it should be emphasized that the spontaneous location of buildings accompanying urban sprawl generates specific spatial conditions, and thus increased costs of infrastructure construction and maintenance. An example is the elongated streets and sewage system due to the inability to implement the investment along the shortest line. Therefore, the national budget suffers losses due to the need to transfer additional funds to communes for infrastructure in areas with spontaneous development.

The canonical analysis was proposed for four variants of grouping the analyzed communes $\mathrm{V}(\mathrm{i})$. $\mathrm{V}(1)$ are external communes, meaning all communes around the core cities, regardless of the commune status. $\mathrm{V}(2)$ are all external communes for which $\mathrm{P}(\mathrm{i})<0$. Therefore, it is a collection of external communes where urban sprawl is intense. $\mathrm{V}(3)$ includes only external communes which have the status of a rural commune. These are the units where urban sprawl is most commonly recognized in Poland whereas V(4) are 
those rural communes for which $\mathrm{P}(\mathrm{i})<0$; ie villages with intensified urban sprawl. $\mathrm{V}(4)$ are therefore units with extreme conditions for urban sprawl. Variation of the canonical analysis aims to observe and increase the accuracy of the assessment of the impact of urban sprawl on the national budget.

In the study, the conclusions from the canonical analysis were made on the basis of the canonical weights and the canonical correlation $R(k)$. The canonical weights indicate the direction of the relationship between the accepted substitutes from the two sets through the signs (+) and (-). Moreover, the significance of a pair of canonical variables was assessed using the Barlett significance test. In contrast, $\mathrm{R}(\mathrm{k})$ represents the general correlation index between two sets of variables, thus indicating the level of relationship between the spatial structure and budget transfers.

The third stage of the research involves verification of $\mathrm{H}(2)$. The basic method of hypothesis verification is standardized mean difference (SMD). SMD is based on a quasiexperimental approach that uses the synthetic control method. The essence of such tests is to identify the control group against which the test group is assessed. It was proposed that the study consisted in comparing the local GDP(per capita) for communes with high urban sprawl with the local GDP(per capita) for the control group.

$$
\operatorname{SMD}_{\mathrm{n}}=\frac{\varphi_{(\alpha)-} \varphi_{(\beta)}}{\mathrm{s}}
$$

where:

$$
\begin{aligned}
& \varphi \text {-GDP(per capita) } \\
& \alpha \text {-assessed group } \\
& \beta \text {-control group } \\
& s \text { - standard deviation }
\end{aligned}
$$

In Poland there is no aggregated GDP at the local level. The lack of GDP at the local level forces a substitution measure. In Polish study tax revenues of municipalities are used interchangeably [77]. Zaucha et al. indicates substantive argument that taxes are associated with the production arising in the territory [77]. In this light, it would be the most appropriate measure of corporate income taxes (CIT). However, the complexity of the Polish tax system prevents such an approach for several reasons: (a) taxes are paid at the place of headquarters and not at the site of product/service; (b) the existence of tax exemptions (e.g., special economic zones); (c) the ability to cover losses from one year to the next tax year. In contrast, personal income taxes (PIT) despite the fact that it has some shortcomings (e.g., the discharge of the tax in place of registration and not in a product/service) have less interference. In addition, Zaucha et al. proposes to add to the revenue the sum of PIT revenue and agricultural tax due to the fact that agricultural holdings do not pay PIT only agricultural tax (AT) [77]. Moreover, Lityński [78], using PIT and AT for research on the local economy, indicates that such an approximation is correlated with GDP at the level of $r=0.98(\mathrm{p}=0.00)$. Therefore, in this study, an approximation of $\mathrm{GDP}$ (per capita) was proposed according to the formula:

$$
\varphi_{(\mathrm{i})}=\frac{\sum_{\mathrm{i}=1}^{\mathrm{n}} \frac{\left[\mathrm{pit}_{(\mathrm{i})}+\mathrm{at}_{(\mathrm{i})}\right]}{\mathrm{N}}}{\mathrm{n}}
$$

where:

$\mathrm{N}$-population of the commune $\mathrm{i}$

$\mathrm{n}$-number of communes

As the analysis is dynamic, i.e., it concerns the years 2010-2019, the index of the medium-term rate of changes was used for the dynamics:

$$
\overline{\mathrm{T}}_{(\mathrm{n})}=\left(\sqrt[\mathrm{n}-1]{\mathrm{i}_{\left(\frac{\mathrm{n}}{\mathrm{n}-1}\right)} * \ldots * \mathrm{i}_{\left(\frac{2}{1}\right)}}-1\right) * 100 \%
$$


All budget data comes from the collections of the Local Data Bank of the Central Statistical Office in Poland.

\section{Results}

Figure 2 shows the Urban Sprawl Index in each of the analyzed communes, which is the implementation of the first stage of the research. As the aim of the first stage of the research is to identify communes with a high and low degree of spatial structure disorder, attention should be paid to the intervals $\mathrm{P}(\mathrm{i})$. Communes with a chaotic spatial structure are those for which $\mathrm{P}(\mathrm{i})<0$. All communes for which $\mathrm{P}(\mathrm{i})<0$ are in the range $(0 ;-1)$, which means a moderate degree of spatial structure disorder. The study did not identify communes with a high degree of disorder $(-1<\mathrm{P}(\mathrm{i}) \leq-2)$ and a very high degree of disorder $(-2<\mathrm{P}(\mathrm{i}) \leq-3)$. However, most communes for which $\mathrm{P}(\mathrm{i})>0$ are in the range $(0 ; 1)$. These communes are characterized by a moderate degree of space compactness. Only one commune is characterized by a very compact spatial structure, for which $\mathrm{P}(\mathrm{i})=2.13$ and it is a rural commune of Wielka Wieś.

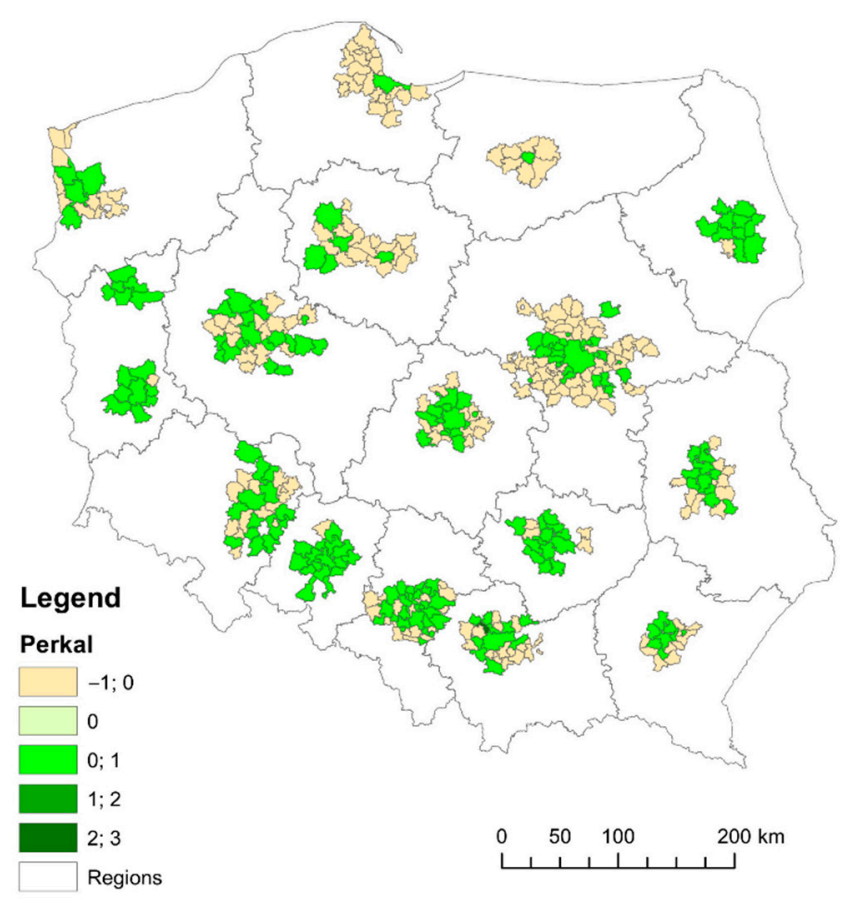

Figure 2. Urban Sprawl Index in the analyzed communes based on the Perkal method P(i). Source: own study based on Lityński [6].

In Poland, the spatial structure of endangered urban sprawl assessed by $\mathrm{P}(\mathrm{i})$, is in the range $(-1 ; 1)$, with one exception. This means that the spatial structure of Polish communes is relatively similar in terms of morphological features of urban sprawl. The level of urban sprawl is not high, but it is also impossible to indicate that the spatial structure is compact. There are no communes in Poland with an absolutely high urban sprawl level. There is also no group of communes with a compact spatial structure. The only exception here is one commune whose spatial structure is very compact.

The second stage of research, which involves verification of $\mathrm{H}(1)$, was based on the canonical analysis. As part of the canonical analysis, four variants of the relationship between the suburban structure and transfers from the national budget were tested. Table 1 shows the results of testing four variants. The most satisfactory results are provided by $\mathrm{V}(4)$, for which the canonical correlation reaches the highest values of $\mathrm{R}(\mathrm{k})=0.46$. This means that rural communes with a high degree of spatial structure disorder $(\mathrm{Pi}<0)$ have the greatest impact on transfers from the state budget. 
Table 1. Canonical analysis between budget transfers and urban sprawl.

\begin{tabular}{ccccc}
\hline Variants & $\mathbf{R}_{(\mathbf{k})}$ & $\mathbf{C h i}^{\mathbf{2}}$ & $\mathbf{p}$ & $\mathbf{N}$ \\
\hline $\mathrm{V}_{(1)}:$ External communes & 0.31 & 64.61 & 0.00 & 370 \\
$\mathrm{~V}_{(2)}:$ External communes; $\mathrm{P}_{(\mathrm{i})}<0$ & 0.33 & 42.18 & 0.00 & 200 \\
$\mathrm{~V}_{(3)}$ : Villages & 0.44 & 54.38 & 0.00 & 221 \\
$\mathrm{~V}_{(4)}$ : Villages; $\mathrm{P}_{(\mathrm{i})}<0$ & 0.46 & 47.98 & 0.00 & 141 \\
\hline
\end{tabular}

The further part of the canonical analysis refers only to $\mathrm{V}(4)$, because this variant provides the most favorable results for the verification of the adopted hypothesis. Table 2 presents the results of testing the significance of pairs of canonical variables based on the Barlett test. The assessment of the significance of pairs of canonical variables, based on the critical values of the significance level (p), indicates that at the significance level $(\alpha)>0.00$ only the first pair of variables is significant. The remaining pairs of variables are so high $(p)$ that the conclusion was abandoned.

Table 2. Barlett test for $\mathrm{V}_{(4)}$.

\begin{tabular}{cccccc}
\hline Element Removed & $\mathbf{R}_{(\mathbf{k})}$ & $\mathbf{R}_{\mathbf{( k )}}{ }^{\mathbf{2}}$ & $\mathbf{C h i}^{\mathbf{2}}$ & $\mathbf{D f}$ & $\mathbf{p}$ \\
\hline 0 & 0.46 & 0.21 & 47.98 & 18.00 & 0.00 \\
1 & 0.25 & 0.07 & 15.44 & 10.00 & 0.12 \\
2 & 0.22 & 0.05 & 6.43 & 4.00 & 0.17 \\
\hline
\end{tabular}

Based on the results presented in Table 3, it can be indicated the greatest positive relationship between the SGS variable and $\mathrm{D}(\mathrm{iu})$. There is no statistically significant negative relationship in the study, i.e., indicating that a higher value of budget transfers is accompanied by a lower level of the morphological variable. Thus, the results of the canonical analysis do not indicate a negative impact of urban sprawl on the state budget.

Table 3. Canonical weights for $\mathrm{V}_{(4)}$.

\begin{tabular}{cccccccc}
\hline & \multicolumn{3}{c}{ Right Set } & & \multicolumn{2}{c}{ Left Set } \\
& Elem. 1 & Elem. 2 & Elem. 3 & & Elem. 1 & Elem. 2 & Elem. 3 \\
\hline SGS & 0.67 & -0.48 & -0.58 & $\mathrm{D}_{(\mathrm{iu})}$ & 0.97 & -1.02 & 0.25 \\
SOCT & -0.63 & -0.76 & -0.18 & $\mathrm{C}_{(\mathrm{iu})}$ & 0.11 & 0.68 & 0.55 \\
SOIT & -0.34 & 0.54 & -0.77 & COV $_{(\mathrm{iu})}$ & 0.24 & -1.42 & 0.26 \\
& & & & CLUS $_{(\mathrm{iu})}$ & -0.02 & 0.22 & 1.06 \\
& & & $\mathrm{CBD}_{(\mathrm{dist})}$ & -0.10 & 0.01 & -0.70 \\
& & & $\mathrm{UP}_{(\mathrm{j} \rightarrow \mathrm{i})}$ & 0.05 & 1.42 & 0.00 \\
\hline
\end{tabular}

Therefore, the conclusions from the canonical analyzes carried out indicate that it cannot be said that the disorder of the spatial structure accompanying the urban sprawl phenomenon has a negative impact on the national budget. Thus, it has not been proven that national expenditure is related to negatively valued morphological features, e.g., lower building density. Based on the results of the research, it is not possible to confirm the hypothesis $H(1)$ that urban sprawl adversely affects the financial situation of the national budget.

The third stage of the research, which assumed the verification of $\mathrm{H}(2)$, was based on the SMD method. As the hypothesis takes two territorial levels: local and national, two SMD analyzes were carried out. It was assumed that the assessed group are communes with the highest degree of spatial structure disorder, i.e., rural communes for which $\mathrm{P}(\mathrm{i})<0$. The assessed group in Table 4 is marked as $(\alpha)$. For the assessment of the local impact, the control group is marked as $(\beta 1)$ and consists of rural communes for which $\mathrm{P}(\mathrm{i}) \geq 0$. On the other hand, the control group at the national level is marked as $(\beta 2)$ and they are all communes in Poland. 
Table 4. Approximation of GDP (per capita) in the assessed group and control groups, Polish currency (PLN).

\begin{tabular}{cccccccccccc}
\hline & $\mathbf{2 0 1 0}$ & $\mathbf{2 0 1 1}$ & $\mathbf{2 0 1 2}$ & $\mathbf{2 0 1 3}$ & $\mathbf{2 0 1 4}$ & $\mathbf{2 0 1 5}$ & $\mathbf{2 0 1 6}$ & $\mathbf{2 0 1 7}$ & $\mathbf{2 0 1 8}$ & $\mathbf{2 0 1 9}$ & $\boldsymbol{T}_{(\boldsymbol{n})}$ \\
\hline$\varphi_{(\alpha)}$ & 496 & 548 & 604 & 654 & 702 & 767 & 832 & 915 & 1038 & 1164 & $11 \%$ \\
$\varphi_{(\beta 1)}$ & 555 & 611 & 670 & 711 & 768 & 835 & 905 & 993 & 1140 & 1275 & $11 \%$ \\
$\varphi_{(\beta 2)}$ & 628 & 685 & 727 & 768 & 826 & 892 & 957 & 1040 & 1175 & 1293 & $9 \%$ \\
\hline
\end{tabular}

Table 4 presents raw data on the approximation of GDP(per capita) for the assessed group and control groups. It points out the same $\bar{T}_{(\alpha)}$ and $\bar{T}_{(\beta 1)}$. This means that the economic growth was the same both in communes with high urban sprawl rates and in spatially compact communes. On the other hand, a lower $\overline{\mathrm{T}}_{(\beta 2)}$ means that the national GDP(per capita) grows slower than in communes with urban sprawl.

In Table 4 lower values of $\varphi_{(\alpha)}$, than $\varphi_{(\beta 1)}$ and $\varphi_{(\beta 2)}$ also draw attention. This means that in communes with high urban sprawl rates, the level of GDP (per capita) is lower than in communes with a more compact spatial structure or in the country. This level was assessed using the SMD method, the results of which are presented in Table 5 The SMD values in the range $0.2-0.5$ are marked in gray, which means a moderate effect. The study did not identify a large or very large effect.

Table 5. Assessment of the impact of urban sprawl on local and national economic growth using the standardized mean difference (SMD) method.

\begin{tabular}{rrrrrrrrrr}
\hline $\mathbf{2 0 1 0}$ & $\mathbf{2 0 1 1}$ & $\mathbf{2 0 1 2}$ & $\mathbf{2 0 1 3}$ & $\mathbf{2 0 1 4}$ & $\mathbf{2 0 1 5}$ & $\mathbf{2 0 1 6}$ & $\mathbf{2 0 1 7}$ & $\mathbf{2 0 1 8}$ & $\mathbf{2 0 1 9}$ \\
\hline$S M D_{(\beta 1)}-0.21$ & -0.21 & -0.22 & -0.18 & -0.20 & -0.19 & -0.19 & -0.18 & -0.21 & -0.21 \\
$S M D_{(\beta 2)}-0.46$ & -0.46 & -0.42 & -0.36 & -0.38 & -0.35 & -0.33 & -0.30 & -0.29 & -0.25 \\
\hline
\end{tabular}

$S M D_{(\beta 1)}$, which assesses the impact of urban sprawl on the local economy, is moderately negative. This allows to conclude that the impact of urban sprawl on the local economy is negative. Moreover, changes in $S M D_{(\beta 1)}$ in 2010-2019 show a stabilized negative trend, which means that urban sprawl communes are not catching up with communes with a more compact structure. Therefore, it can be concluded that urban sprawl slows down economic growth and economic development. This impact can be assessed as negative at a moderate level. It is possible to confirm the hypothesis that urban sprawl slows down local economic growth.

$S M D_{(\beta 2)}$, which assesses the impact of urban sprawl on the national economy, is also moderately negative. The tendency of changes in $S M D_{(\beta 2)}$ in 2010-2019 indicates a reduction of the negative impact, but the impact is still moderate. This reduction results from the higher $\overline{\mathrm{T}}_{(\alpha)}$ than $\overline{\mathrm{T}}_{(\beta 2)}$. Thus, the impact of urban sprawl on the national economy is not clearly negative. Even though $S M D_{(\beta 2)}$ is negative at a moderate level, the trend of changes indicates a clear improvement. Therefore, the hypothesis about the impact of urban sprawl on the slowdown of the national economy cannot be clearly confirmed.

Two main conclusions can be drawn from the above results. The first is that urban sprawl adversely affects the local economy and its growth. The second, urban sprawl, does not adversely affect the national economy. It also has no negative impact on the national budget. These conclusions are essential for spatial policy. Sprawl does not harm the national economy and the national budget, but communes with a compact structure are important for the dynamization of economic development. The research results confirm that compact communes represent a higher economic level than the national level, and thus have a positive impact on the national economy. For the national economy, the cost of sprawl is the lack of utilization of the development potential of the suburban space. Therefore, spatial policy should not be guided by absolute limitation of urban sprawl, because it has no detrimental effect on the national economy. Policy should focus on guiding the sprawl. This direction should consist in stimulating the formation of suburban housing estates with a compact structure. In the light of research, spatially compact communes dynamize 
economic development. Therefore, an important role should be played by instruments stimulating positive spatial phenomena, and not restrictive ones preventing sprawl. The formation of compact structures will contribute to the use of the growth potential not only for the economies of the communes themselves, but also for the country.

\section{Conclusions and Discussion}

The contribution of the research in the development of the current state of knowledge can be noticed in the methodical and theoretical dimension, according to the set hypothesis. The added value in the methodological layer is the measurement of the impact of urban sprawl on national budget, taking into account the morphological variables. It fills the gap in the current state of knowledge regarding the explanation of the mechanism of linking the spatial and budgetary structure. It is significant for the spatial economy and public finances. Determining this mechanism allows for the formulation of spatial and fiscal policies or the integration of spatial planning with socio-economic planning. The conducted research shows that from the macroeconomic point of view, urban sprawl is not a process generating direct costs. However, it is a process that slows down economic growth, and communes with a compact structure are important to accelerate the pace of economic growth. As the assessment of urban sprawl losses is not unequivocally negative, the spatial policy should not focus on the absolute reduction of urban sprawl, but on stimulating the formation of suburban housing estates with a compact structure. We must bear in mind that urban sprawl can have either a positive or negative impact on the space and its other users, which will be equated with benefit or costs. However, the determination of externalities and their size is extremely difficult due to the existing market failures and the impact of this market on the processes taking place in it. What is significant, however, is that the inducers of urban sprawl may not even realize that they are producers of externalities. On the other hand, the remaining entities operating in space experience the resulting external effects [79]. Therefore, according to Papandreou [80], spatial policy should take into account the behavior of entities causing urban sprawl. Taking this into account, on the basis of research results, should be based on the use of instruments stimulating positive spatial phenomena. This means that entities deciding to build should be encouraged to locate among the existing buildings, creating a compact spatial structure. However, restrictive instruments to prevent urban sprawl should not be used, as sprawl is not a macro-economic loss-making process.

The presented conclusion, in light of the literature, justifies the need to combine spatial policy of the national level with the local level. This combination is expressed not only in the coherence of spatial plans, the assumptions of which would focus development into compact spatial structures. It pertains primarily to equipping local government by central authorities with operational instruments for implementing spatial plans. Stimulating compact development at the local level requires financial as well as organizational and legal resources. For the correct functioning of a coherent planning system, active participation of residents along with an efficient public administration system will be important. Here it will be necessary to implement a common, acceptable spatial policy resulting in efficiency resulting from the cooperation of space users. Policy creating conditions for the exploitation of the identified development potentials in suburban areas [81,82].

It seems that financial instruments can play a decisive role in stimulating the formation of compact spatial structures. In this group, attention should be paid to indirect instruments such as exemptions or tax breaks for new compact housing locations. Local self-government should receive compensation from the national budget for the reduction of revenues, which takes place through the application of such understood tax exemption or relief. Another, indirect financial instrument could be a public fund offering credit facilities for the implementation of compact housing investments. There are no such instruments in Poland.

On the other hand, among direct financial instruments, a higher level of subsidizing infrastructure investments is proposed, which would result in the emergence of compact development. In Poland, there are so-called earmarked subsidies, which are a transfer from 
the national budget to local budgets to secure infrastructure investments. The transfer limit is generally $80 \%$ of the cost. There is, therefore, a range of an additional $20 \%$ that could be allocated to suburban communes.

The use of stimulating financial instruments creates the risk of an externality, which may be increasing the range of urban sprawl [51]. This may be the case of the anticipatory approach of local authorities to shaping undeveloped suburban space, including equipping it with attractive technical infrastructure. In our perspective, however, the use of stimulating financial instruments should be reserved only for supplementing the development between existing buildings. The point is to transform the current disordered structure of space into a compact form. The creation of completely new suburban housing estates on greenfields should not be stimulated by the public sector, but rather be subject to appropriate planning and implementation control. Control and planning on greenfields should be strengthened with legal and organizational instruments, i.e., organizational standards and administrative decisions. Strengthening the regulatory function of spatial planning, especially through organizational standards, would allow for effective and sustainable land use (e.g., in terms of protection of areas particularly suitable for agricultural production); compliance with the principles of environmental and landscape protection; compliance with safety rules; use the dimensions of buildings in accordance with the urban and architectural requirements [51]. In the case of administrative decisions made at the lowest level of public administration, we see the importance of skills, knowledge and intuition. In agreement with Śleszyński et al. [83] we believe that the spatial policy implemented at the commune level, despite the standardized organizational norms, will be able to produce individualized positive externalities of urban sprawl with appropriate use of administrative decisions.

Stimulating compact development encounters difficulties resulting from the acceptance of costs on the part of society, as indicated by Meade [84]. Then, these costs may, to a limited extent, constitute the basis for verification of the conducted spatial policy and the introduction of restrictive instruments. Hence, we agree with the finding of Baumol et al. [85], that it is necessary to evaluate the effectiveness of national intervention by comparing the potential benefits of reducing social costs with the generated effects for the national budget. Our conclusions about the lack of macroeconomic net costs of urban sprawl justify that, from the point of view of the country, one should be cautious about applying restrictive instruments. The absence of these losses for the economy as a whole means that the government does not have strong arguments for restrictive treatment of urban sprawl in public policy, especially when social losses are accepted. Therefore, there is no justification, for example, to reduce budget transfers for infrastructure investments resulting in the dispersion of buildings. It is true that in Poland there is no such reduction in transfers; however, this example demonstrates the difficulty of creating a compact spatial structure. Since the central authorities does not have an economic interest in preventing urban sprawl, it will be even more difficult to stimulate compact spatial structure. Hence, more important is the appropriate design of the system of financial instruments to stimulate compact development.

The research results are an extension of the current state of knowledge on the macroeconomic impact of urban sprawl. However, like many original concepts, they may have some limitations, which sometimes makes it difficult to formulate universal conclusions for the international scale. Firstly, the impact of sprawl on the financial situation of the national's budget was based on subsidies for communes specific to Polish public finances. Both the types of subsidies and the mechanisms for granting them are strictly defined in Polish law. Therefore, the conclusions about the impact on the national budget are, first of all, adequate for Poland. These conclusions may be valid for countries where the system of transfers from the national budget to the communes' budgets distinguishes subsidies related to co-financing the costs of infrastructure investments due to specific geographic conditions. Second, the impact of urban sprawl on the growth rate of local and national economies was determined on the basis of regional capitals. These are the most important 
cities in Poland, but there is still a remaining group of medium-sized and smaller cities in the hierarchy of the national settlement system. There is also urban sprawl around smaller towns. It should be noted that the aforementioned limitations also set the directions for future research. An extension of the presented conclusions could be the assessment of the impact of urban sprawl in the configuration of the urban system, e.g., monocentric vs. polycentric; regional vs. subregional cities. It is also possible to adopt a different impact on the national budget than through transfers, which would be a country-specific approach. It seems that due to the different legal structures of the system of income and expenditures from the national budget, it is difficult to build an internationally universal research model.

Author Contributions: Conceptualization, P.L. and A.H.; methodology, P.L.; software, P.L. and A.H.; validation, P.L. and A.H.; formal analysis, P.L.; investigation, P.L. and A.H.; resources, P.L. and A.H.; data curation, P.L.; Writing-Original draft preparation, P.L. and A.H.; literature review A.H.; Writing-Review and editing, P.L., and A.H.; visualization, A.H.; supervision, P.L. and A.H.; All authors have read and agreed to the published version of the manuscript.

Funding: This research was funded by the National Science Centre, Poland; grant no. UMO2016/23/D/HS4/02961, ("Financial Mechanisms in the Economy Resulting from the Phenomenon of Urban Sprawl") and Cracow University of Economics, Poland, POTENTIAL Program No.52/GGR/2020/POT. ("Cities, suburbs and peripheries in the theory and in the empirical studies").

Institutional Review Board Statement: Not applicable.

Informed Consent Statement: Not applicable.

Data Availability Statement: Publicly available datasets were analyzed in this study. Fiscal data was obtained from Central Statistical Office in Poland https://bdl.stat.gov.pl/BDL/start; spatial data was obtained from the appendices in the book [6].

Acknowledgments: Not applicable.

Conflicts of Interest: The authors declare no conflict of interest.

\section{References}

1. Whyte, W.H. The Exploding Metropolis: A Study of the Assault on Urbanism and How Our Cities Can Resist It; A Doubleday Anchor Book: New York, NY, USA, 1958.

2. Perrsky, J.; Wiewel, J. Urban Decentralization, Suburbanization, and Sprawl: An Equity Perspective. In Urban Economics and Planning; Brooks, N., Donaghy, K., Knaap, G.J., Eds.; Oxford University Press: New York, NY, USA, 2012; ISBN 978-0195380620.

3. Arribas-Bel, D.; Nijkamp, P.; Scholten, H. Multidimensional urban sprawl in Europe: A self-organizing map approach. Comput. Environ. Urban Syst. 2011, 35, 263-275. [CrossRef]

4. Galster, G.; Hanson, R.; Wolman, H.; Coleman, S.; Freihage, J. Wrestling sprawl to the ground: Defining and measuring an elusive concept. Hous. Policy Debate 2001, 12, 681-717. [CrossRef]

5. Lityński, P.; Hołuj, A.; Zotic, V. The Polish Urban Sprawl: An Economic Perspective. J. Settl. Spat. Plan. 2015, 6, 95-105.

6. Lityński, P. Budżetowe Konsekwencje Żywiołowego Rozprzestrzeniania się Miast dla Samorzadów Gminnych (Urban Sprawl and the Budgetary Consequences Form Municipal Governments); Uniwersytetu Ekonomicznego w Krakowie: Kraków, Poland, 2019; ISBN 978-83-7252-782-0.

7. Mumford, L. The City in History: Its Origins, Its Transformations, and Its Prospects; Harcourt Brace: New York, NY, USA, 1969; ISBN -13 978-0156180351.

8. McHarg, I.L. Design with Nature; Natural History Press: New York, NY, USA, 1969; ISBN -13 978-0471114604.

9. Jackson, K. The Crabgrass Frontier: The Suburbanization of the United States; Oxford University Press: New York, NY, USA, 1985; ISBN -13 978-0195049831.

10. Downs, A. New Visions for Metropolitan America; The Brookings Institution: Washington, DC, USA, 1994; ISBN -13 978-0815719267.

11. Fulton, W.; Pendall, R.; Nguyen, M.; Harrison, A. Who Sprawls Most: How Growth Patterns Differ across the United States; The Brookings Institution: Washington, DC, USA, 2001; Volume 23, pp. 428-434.

12. OECD. Compact City Policies: A Comparative Assessment; OECD Green Growth Studies; OECD Publishing: Paris, France, 2012; ISBN 9789264167841.

13. Young, M.; Tnguay, G.A.; Lachapelle, U. Transportation cos and urban sprawl in Canadian metropolitan areas. Res. Transp. Econ. 2016, 60, 25-34. [CrossRef]

14. O'Toole, R. Gridlock: Why We're Stuck in Traffic and What to Do about It; CATO Institute: Washington, DC, USA, 2009 ; pp. 1-277.

15. Pipień, M.; Roszkowska, S. Empirical Macroeconomics and Statistical Uncertainty: Spatial and Temporal Disaggregation of Regional Economic Indicators; Routledge Studies in the European Economy: New York, NY, USA, 2020; ISBN 13 978-0367456719. 
16. Mankiw, N.G.; Romer, D.; Weil, D. A Contribution to the Empirics of Economic Growth. Q. J. Econ. 1992, 107, 2. [CrossRef]

17. Capello, R. Spatial Spillovers and Regional Growth: A Cognitive Approach. Eur. Plan. Stud. 2009, 17, 5. [CrossRef]

18. Gruber, J. Public Finance and Public Policy, 4th ed; Worth Publishers: New York, NY, USA, 2012; ISBN -13 978-1429278454.

19. Irwin, E.; Bockstael, N. Land use externalities, open space preservation and urban sprawl. Reg. Sci. Urban Econ. 2004, 34, 705-725. [CrossRef]

20. Nijkamp, P.; Verhoef, E.T. Externalities in the Urban Economy; Tinbergen Institute Discussion Paper; Vrije Universiteit: Amsterdam, The Netherlands, 2003; TI 2003-078/3.

21. Treacy, J. Smart methods for environmental externalities: Urban planning, environmental health and hygiene in the Netherlands. Irish Geogr. 2014, 46, 3. [CrossRef]

22. Kowalewski, A.; Markowski, T.; Śleszyński, P. Kryzys Polskiej Przestrzeni. Źródła, Skutki i Kierunki Działań Naprawczych; Polska Akademia Nauk, Komitet Przestrzennego Zagospodarowania Kraju: Warsaw, Poland, 2020; ISBN 978-83-63305-83-3.

23. Bromley, R.D.F.; Tallon, A.R.; Roberts, A.J. New populations in the British city centre: Evidence of social change from the census and household surveys. Geoforum 2007, 38, 1. [CrossRef]

24. Colomb, C. Unpacking new labour's Urban Renaissance agenda: Towards a socially sustainable reurbanization of British cities? Plan. Pract. Res. 2007, 22, 1-24. [CrossRef]

25. Turok, I.; Mykhnenko, V. The trajectories of European cities, 1960-2005. Cities 2007, 24, 165-182. [CrossRef]

26. Cheshire, P.C.; Gordon, I. Resurgent cities? Evidence-based Urban Policy? More Questions than Answers-Special issue. Urban Stud. 2006, $43,8$.

27. Pigou, A.C. Economics of Welfare; Macmillan Company: London, UK, 1952.

28. Samuelson, P.A. Zasady Analizy Ekonomicznej; PWN: Warsaw, Poland, 1959.

29. Krugman, P.; Wells, R. Economics, 2nd ed.; Worth Publishers: New York, NY, USA, 2009; ISBN -13 978-0716771616.

30. Gruber, J. Public Finance and Public Policy, 5th ed; Worth Publishers: New York, NY, USA, 2015; ISBN 13 978-1464143335.

31. Hołuj, A. Ekonomiczne i ekologiczne efekty zewnętrzne w planowaniu przestrzennym. Acta Universitatis Lodziensis. Folia Oeconomica 2018, 4, 336. [CrossRef]

32. Markowski, T. Planowanie przestrzenne i instrumenty jego realizacji w świetle teorii ułomnych rynków. In Zarządzanie Rozwojem Przestrzennym Miast; Lorens, P., Martyniuk-Pęczek, J., Eds.; Wydawnictwo Urbanistyka: Gdańsk, Poland, 2010.

33. Żylicz, T. Ekonomia Środowiska i Zasobów Naturalnych; PWE: Warsaw, Poland, 2004; ISBN 83-208-1521-5.

34. EEA Report, Urban Sprawl in Europe. The Ignored Challenge. No 10/2006; European Environment Agency: Copenhagen, Denmark, 2006; ISSN 1725-9177.

35. Albrecht, D.E. Nonmetropolitan population trends: Twenty first century updates. J. Rural Soc. Sci. 2010, 25, 1-21.

36. Sant, M.; Simons, P. The conceptual basis of counterurbanisation: Critique and development. Aust. Geogr. Stud. 1993, 31, 113-126. [CrossRef]

37. Dahms, F.; McComb, J. Counterurbanization, interaction and functional change in a rural amenity area-A Canadianexample. J. Rural Stud. 1999, 15, 2.

38. White, P. Labour migration and counter-urbanization in France. In Labour Migration: The Internal Geographical Mobility of Labour in the Developed World; Johnson, J., Salt, J., Eds.; David Fulton Publishers: London, UK, 1990; ISBN 978036703458-1.

39. Phillips, M. Counterurbanisation and rural gentrification: An exploration of the terms. Popul. Space Place 2010, 16, 6. [CrossRef]

40. Jauhiainen, J.S. Will the retiring baby boomers return to rural periphery? J. Rural Stud. 2009, 25, 25-34. [CrossRef]

41. Bijker, R.; Haartsen, T.; Strijker, D. Migration to less-popular rural areas in the Netherlands: Exploring the motivations. J. Rural Stud. 2012, 28, 490-498. [CrossRef]

42. Champion, A.; Vandermotten, C. Migration, counterurbanisation and regional re-structuring in Europe. In People, Jobs and Mobility in New Europe; Blotevogel, H., Fielding, A.J., Eds.; John Wiley: Chichester, UK, 1997; pp. 69-90.

43. Champion, A.G.; Watkins, C. People in the Countryside: Studies of Social Change in Rural Britain; Paul Chapman: London, UK, 1990; ISBN -10 1853961280.

44. Beale, C.L. A further look at nonmetropolitan population growth since 1970. Am. J. Agric. Econ. 1976, 58, 953-958. [CrossRef]

45. Berry, B.J.L. The counterurbanization process: Urban America since 1970. Urban Af-Fairs Annu. Rev. 1976, 11, 17-30.

46. Mithell, C.J.A.; Briant, C.R. Counterurbanization. In International Encyclopedia of Human Geography; Kitchin, R., Thrift, N., Eds.; Elsevier: Maynooth, Ireland, 2009; ISBN 9780080449104.

47. Wamsley, D.J.; Epps, W.R.; Duncan, C.J. Migration to the New South Wales north coast 1986-1991: Lifestyle motivated counterurbanisation. Geoforum 1998, 29, 105-118. [CrossRef]

48. Steenbekkers, A.; Simon, C.; Veldheer, V. Thuis op het Platteland: De Leefsituatie van Platteland en Stad Vergeleken; Sociaal en Cultureel Planbureau: The Hague, The Netherlands, 2006; ISBN 90-377-0229-5.

49. Geyer, H.S.; Kontuly, T. A theoretical foundation for the concept of differential urbanization. Int. Reg. Sci. Rev. 1993, 15, 2. [CrossRef]

50. Docampo, M.G. Theories of Urban Dynamics. Int. J. Popul. Res. 2014, 2014, 11. [CrossRef]

51. Burchell, R.W.; Downs, A.; McCann, B.; Mukherji, S. Sprawl Costs. Economic Impacts of Unchecked Development; Island Press: Washington, DC, USA, 2005; ISBN 978-1559635707.

52. Beale, C.L.; Fuguitt, G. Decade of pessimistic nonmetro population trends ends on optimistic note. Rural Dev. Perspect. 1990, 6, 14-18. 
53. Couch, C.; Karecha, J.; Nuissl, H.; Rink, D. Decline and sprawl: An evolving type of urban development-observed in Liverpool and Leipzig. Eur. Plan. Stud. 2005, 13, 117-136. [CrossRef]

54. Haase, A.; Kabisch, S.; Steinfuhrer, A.; Bouzarovski, S.; Hall, R.; Ogden, P. Emergent spaces of reurbanisation: Exploring the demographic dimension of inner-city residential change in a European setting. Popul. Space Place 2010, 16, 5. [CrossRef]

55. Méndez, R. Crisis, vulnerabilidad y nuevas desigualdades territoriales en España. Sistema 2015, 239, 45-63.

56. Burriel, E.L. Subversion of land-use plans and the housing bubble in Spain. Urban Res. Pract. 2011, 4, 232-249. [CrossRef]

57. García, M. The Breakdown of the Spanish Urban Growth Model: Social and Territorial Effects of the GlobalCrisis. Int. J. Urban Reg. Res. 2010, 34, 967-980. [CrossRef]

58. Lois, R.C.; Piñeira, M.J. The revival of urban social and neighbourhood movements in Spain: A geographical characterization. Die Erde 2015, 146, 127-138.

59. Lityński, P.; Hołuj, A. Urban Sprawl Costs: The Valuation of Households' Losses in Poland. J. Settl. Spat. Plan. 2017, 8, 11-35. [CrossRef]

60. Heffner, K. Czynniki Osadnicze Wpływające na Potencjał Rozwojowy Obszarów Wiejskich. In Wieś $i$ Rolnictwo 2; IRWIR PAN: Warsaw, Poland, 2002; pp. 27-48.

61. Hoggart, K.; Paniagua, A. The restructuring of rural Spain? J. Rural Stud. 2001, 17, 63-80. [CrossRef]

62. Hołuj, D.; Hołuj, A. Mechanisms of Densification of the City in the Neoliberal Economy-A Case Study: The Surroundings of the Eastern Part of the Former Airport Runway Rakowice-Czyżyny in Cracow. Bull. Geogr. Socio-Econ. Ser. 2015, 27, 81-93. [CrossRef]

63. Słodczyk, J. Gospodarka przestrzenna-pojęcia podstawowe. In Podstawy Gospodarki Przestrzennej—Wybrane Aspekty; Korenik, S., Słodczyk, J., Eds.; Wrocław University of Economics: Wrocław, Poland, 2005.

64. Newman, P.; Thornley, A. Urban Planning in Europe: International Competition, National Systems, and Planning Projects; Psychology Press, Routledge: London, UK; New York, NY, USA; 1996; ISBN 0-203-73618-4.

65. OECD. Land-Use Planning Systems in the OECD: Country Fact Sheets; OECD Publishing: Paris, France, 2017; ISBN 978-92-64-26857-9.

66. Reimer, M.; Getimis, P.; Blotevogel, H. (Eds.) Spatial Planning Systems and Practices in Europe. A Comparative Perspective on Continuity and Changes, 1st ed.; Routledge: New York, NY, USA, 2014; ISBN 9780415727242.

67. Zambon, I.; Cerdà, A.; Gambella, F.; Egidi, G.; Salvati, L. Industrial Sprawl and Residential Housing: Exploring the Interplay between Local Development and Land-Use Change in the Valencian Community, Spain. Land 2019, 8, 143. [CrossRef]

68. Serra, P.; Vera, A.; Tulla, A.F.; Salvati, L. Beyond urban-rural dichotomy: Exploring socioeconomic and land-use processes of change in Spain (1991-2011). Appl. Geogr. 2014, 55, 71-81. [CrossRef]

69. Gomez-Antonio, M.; Hortas-Rico, M.; Li, L. The Causes of Urban Sprawl in Spanish Urban Areas: A Spatial Approach. Spat. Econ. Anal. 2014, 11, 2. [CrossRef]

70. Catalán, B.; Saurí, D.; Serra, P. Urban sprawl in the Mediterranean? Patterns of growth and change in the Barcelona Metropolitan Region 1992-2000. Landsc. Urban Plan. 2008, 85, 174-184. [CrossRef]

71. Torrens, P. A toolkit for measuring sprawl. Appl. Spat. Anal. Policy 2008, 1, 5-36. [CrossRef]

72. Saiz, A. The geographic determinants of housing supply. Q. J. Econ. 2010, 125, 1253-1296. [CrossRef]

73. García-López, M.A. Urban spatial structure, suburbanization and transportation in Barcelona. J. Urban Econ. 2012, 72, 176190. [CrossRef]

74. Śleszyński, P.; Gibas, P.; Sudra, P. The Problem of Mismatch between the CORINE Land Cover Data Classification and the Development of Settlement in Poland. Remote Sens. 2020, 12, 2253. [CrossRef]

75. Lityński, P.; Hołuj, A. Urban Sprawl Risk Delimitation: The Concept for Spatial Planning Policy in Poland. Sustainability 2020, 12, 2637. [CrossRef]

76. OECD. Rethinking Urban Sprawl: Moving Towards Sustainable Cities; OECD Publishing: Paris, France, 2018.

77. Zaucha, J.; Brodzicki, T.; Ciołek, D.; Komornicki, T.; Mogiła, Z.; Szlachta, J.; Zaleski, J. Terytorialny Wymiar Wzrostu i Rozwoju. Spójność, Potencjały i Użyteczność [The Territorial Dimension of Growth and Development. Consistency, Potentials and Utility]; Difin: Warsaw, Poland, 2015; pp. 120-121. ISBN 978-83-7930-939-2.

78. Lityński, P. The Correlation between Urban Sprawl and the Local Economy in Poland; Urban Challenge, Urban Planning Institute of the Republic of Slovenia: Ljubljana, Slovenia, 2016; Volume 27, pp. 86-96.

79. Nowak, M.J. Niesprawność Władz Publicznych a System Gospodarki Przestrzennej; KPZK, PAN, Studia, CLXXV: Warsaw, Poland, 2017; ISBN 9788363563301.

80. Papandreou, A.A. Externality and Institutions; Clarendon Press: Oxford, UK, 1994; ISBN 978-0198287759.

81. Bourne, L.S. Urban Systems: Strategies for Regulation; Clarendon Press: Oxford, UK, 1975.

82. Mickiewicz, P.; Nowak, M.J.; Mickiewicz, B.; Zvirbule, A. Environmental protection and integrated development planning in local spatial policy on the example of Poland. Ann. Univ. Apulensis Ser. Oeconomica 2020, 22, 11-17.

83. Śleszyński, P.; Kowalewski, A.; Markowski, T.; Legutko-Kobus, P.; Nowak, M. The Contemporary Economic Costs of Spatial Chaos: Evidence from Poland. Land 2020, 9, 214. [CrossRef]

84. Meade, J.E. External Economies and Diseconomies in a Competitive Situation. Econ. J. 1952, 62, 245. [CrossRef]

85. Baumol, W.; Oates, W. Externalities: Definition, significant types, and optimal-pricing conditions. In The Theory of Environmental Policy; Cambridge University Press: Cambridge, UK, 1988; pp. 14-35. [CrossRef] 